\title{
Perbandingan Efektivitas Produk Filgrastim pada Pasien Keganasan Limfoma yang Menerima Kemoterapi di RSUP dr. Sardjito Yogyakarta
}

\section{Comparison of The Effectiveness of The Product Filgrastim in Patients with Lymphoma Malignancies Receiving Chemotherapy in dr. Sardjito Yogyakarta}

\author{
Dhien Setiani ${ }^{1}$, Zulies Ikawati ${ }^{2}$, Kartika Widayati ${ }^{3}$ \\ 1'dhiengusmanto@gmail.com, ${ }^{2}$ Ikawati@yahoo.com, ${ }^{3}$ taroena_hariadi@yahoo.com \\ ${ }^{1}$ Magister Farmasi Klinik, Universitas Gajah Mada \\ ${ }^{2}$ Fakultas Farmasi, Universitas Gadjah Mada \\ ${ }^{3}$ RSUP Dr. Sardjito, Yogyakarta \\ Jalan Sekip Utara Yogyakarta
}

\begin{abstract}
Abstrak
Neutropenia adalah toksisitas yang sering terjadi pada pasien kanker limfoma akibat menerima kemoterapi mielotoksik. Granulocyte Colony Stimulating Factor (G-CSF) direkomendasikan secara klinik untuk neutropenia. Filgrastim adalah nama generik dari merk produk G-CSF yang beredar di Indonesia seperti Filgrastim merk A dan Filgrastim merk B yang diproduksi oleh pabrik yang berbeda. Perbedaan Filgrastim merk A dan Filgrastim merk B selain pabrik yang memproduksi adalah harga produk Filgrastim A lebih murah dibandingkan Filgrastim merk B. Perbandingan efektivitas Filgrastim merk A dengan Filgrastim merk B pada pasien di RSUP Dr.Sardjito Yogyakarta perlu diteliti untuk evaluasi terhadap efektivitas jenis obat yang telah dipakai secara klinik. Tujuan penelitian ini adalah membandingkan efektivitas Filgrastim merk A dan Filgrastim merk B pada penggunaan praktek klinik sehari-hari di RSUP Dr. Sardjito Yogyakarta.

Rancangan penelitian ini menggunakan analitik retrospektif cohort study pada pasien yang menerima kemoterapi di Instalasi Kanker Tulip RSUP Dr. Sardjito Yogyakarta. Data diambil dari rekam medik periode Januari 2013 sampai Maret 2015. Perbandingan efektivitas filgrastim menggunakan parameter waktu untuk mencapai Absolute Neutrophil Count (ANC) recovery. Data karakteristik subjek penelitian dianalisis menggunakan Chi Square Goodness of Fit untuk data kategorik dan uji $t$ independent untuk data numerik. Perbandingan efektivitas filgrastim merk $A$ dan merk $\mathrm{B}$ dianalisis menggunakan analisis survival.

Diperoleh sebanyak 80 subjek pasien keganasan limfoma dengan 192 episode kejadian neutropenia yang mendapatkan terapi filgrastim. Dari 80 subjek, hanya 43 subjek (53,5\%) yang terdiri dari 72 episode kejadian neutropenia) yang memenuhi kriteria inklusi (33 kejadian memakai filgrastim merk A dan 39 kejadian filgrastim merk B). Hasil perbandingan efektivitas filgrastim berdasarkan kecepatan waktu meningkatkan ANC recovery menurut analisis survival bivariat Kaplan Meier, dengan data pengamatan laboratorium 24 jam post suntik terakhir, menunjukkan bahwa Filgrastim merk A memiliki median recovery time lebih
\end{abstract}


cepat dibandingkan Filgrastim merk $\mathrm{B}(1,00$ vs 2,00 hari ; $<<0,05)$. Kesimpulan penelitian ini adalah Filgrastim merk $A$ lebih efektif dibandingkan Filgrastim merk B dalam hal kecepatan waktu untuk mencapai ANC recovery.

\title{
Kata kunci : waktu ANC recovery, efektivitas, Filgrastim merk A, Filgrastim merk B.
}

\begin{abstract}
Neutropenia is a common toxicity in cancer patients receiving chemotherapy myelotoxic as lymphoma result. Granulocyte Colony Stimulating Factor (G-CSF) is clinically recommended for neutropenia. Filgrastim is a generic name of the brand G - CSF products circulating in Indonesia such as Filgrastim brand $A$ and brand $B$ produced by a different manufacturer. The differences Filgrastim brand $A$ and brand $B$ produced by non-factory is that Filgrastim A product's price is cheaper than brand $B$. Comparison of the effectiveness of Filgrastim brand $A$ and brand $B$ in patients at DR.Sardjito Hospital Yogyakarta need to be examined to evaluate the effectiveness of the type of drugs has been clinically used. The purpose of this study was to compare the effectiveness of Filgrastim $A$ and $B$ on the use of daily clinical practice at RSUP Dr. Sardjito Yogyakarta.

The design of this study is analytic retrospective cohort study that is applied for patients receiving chemotherapy in cancer Installation Tulip Hospital Dr. Sardjito. Data was retrieved from medical records the period January 2013 to March 2015. Comparison of the effectiveness of filgrastim uses the parameter of time to reach the Absolute Neutrophil Count (ANC) recovery. Data of characteristics subjects were analyzed by using chi square Goodness of Fit for categorical data and independent $t$ test for numerical data. The comparison of effectiveness of filgrastim was analyzed by using survival analysis.

A total of the study showed that there were 80 subjects which consists of 192 episodes of neutropenia incidence of filgrastim therapy. From 80 subjects, there were 43 subjects ( $53,5 \%$ ) which consist of 72 episodes of neutropenic (33 episodes with filgrastim brand $A$ and 39 episodes with filgrastim brand $B$ ) that met the inclusion criteria. The result of the comparison of filgrastim effectiveness based on time to ANC recovery, according to the bivariate Kaplan-Meier with the laboratory observation data 24 hours post last injections, it shows that Filgrastim brand $A$ has a median recovery time faster than Filgrastim brand $B(1,00$ vs 2,00 $p<0,05)$. The conclusions of this study, in the ANC recovery time, Filgrastim brand $A$ more effective than Filgrastim brand $B$.
\end{abstract}

Keywords: ANC recovery time,effectiveness, filgrastim brand A, filgrastim brand $B$.

\section{Pendahuluan}

Neutropenia merupakan komplikasi yang sering terjadi selama kemoterapi yaitu 20 - $40 \%$ pada solid tumor dan 50 - $70 \%$ pada keganasan hematologi. Durasi dan keparahan neutropenia sering menimbulkan kejadian infeksi ketika nilai Absolute Neutrophil Count (ANC) turun dari $1000 / \mu \mathrm{l}$ sampai kurang dari $100 / \mu \mathrm{l}$ (Bolis et al., 2013). Neutropenia akan berdampak pada tertundanya dan berkurangnya dosis regimen kemoterapi sehingga dapat mengganggu outcome berupa kesembuhan dan survival pasien(Crawford et al., 2010).

Menurut Lyman et al., (2014) usia lanjut, kondisi umum yang jelek, keganasan kanker, komorbid, baseline nilai angka sel darah, body mass index yang rendah, penggunaan kemoterapi mielosupresif, genetik polimorfisme, 
berhubungan dengan risiko febrile neutropenia.Filgrastim merupakan recombinant buman Granulocyte-colony Stimulating Factor (rhG-CSF) yang disintesis dari rekombinan DNA sel bakteri E.colli pada manusia, merangsang produksi neutrofil sehingga filgrastim digunakan sebagai terapi maupun profilaksis febrile nentropenia.Hal tersebut membuat pentingnya pemberian Granulocyte Colony Stimulating Factor (GCSF) pada pasien yang menerima regimen mielotoksik kemoterapi untuk mengurangi kejadian neutropenia parah dan insiden febrile neutropenia (Crawford et al., 2010)

Filgrastim adalah nama generik dari berbagai merk produk G-CSF yang beredar di Indonesia, seperti Filgrastim merk A dan Filgrastim merk B yang diproduksi oleh pabrik yang berbeda. Perbedaan Filgrastim merk A dan Filgrastim merk B selain pabrik yang memproduksi adalah harga produk Filgrastim merk A lebih murah dibandingkan Filgrastim merk B. Filgrastim merk B sebagai produk yang sering digunakan dan harga yang lebih mahal perlu diperbandingkan efektivitasnya dengan Filgrastim merk A.

Karena itu pada penelitian ini dilakukan evaluasi perbandingan efektivitas Filgrastim merk A dengan produk Filgrastim merk B yang digunakan pada pasien di RS Sardjito Yogyakarta, dengan melihat kemampuannya dalam waktu mencapai ANC recovery. Hal ini didasarkan pada penelitian sebelumnya oleh Sevince at al., (2014) yang membandingkan efektivitas produk biosimilar filgrastim dengan original filgrastim yang menggunakan parameter waktu ANC recovery. Kecepatan waktu filgrastim dalam mencapai ANC recovery penting untuk diteliti karena efek samping neutropenia apabila terjadi dalam waktu yang panjang akan meningkatkan kejadian infeksi yang serius yang dapat berakibat fatal yaitu kematian (Rifkin et al., 2010).

\section{Metode Penelitian}

Penelitian yang dilakukan ini termasuk jenis penelitian analitik secara cohort retrospektif. Data yang diperlukan untuk penelitian ini dikumpulkan secara retrospektif dan diambil dari catatan medik periode Januari 2013 - Maret 2015. Penelitian ini dilakukan di Instalasi Catatan Medik (ICM) dan Instalasi Kanker Tulip RSUP Sardjito Yogyakarta. Waktu penelitian pada bulan Januari Maret 2015.

\section{Populasi dan Subjek Penelitian}

Subjek penelitian ini adalah semua pasien rawat jalan dan rawat inap dengan diagnosa keganasan limfoma yang menggunakan filgrastim yang dirawat di Instalasi Kanker Tulip dan Instalasi Rawat Inap RSUP Dr. Sardjito Yogyakarta periode Januari tahun 2013 Maret 2015.

\section{Kriteria Inklusi}

1. Pasien laki-laki dan perempuan dengan usia $\geq 18$ tahun.

2. Pasien didiagnosa keganasan limfoma yaitu Non Hodgkin Lymphoma(NHL), atau Hodgkin Lymphoma (HL) yang mendapatkan kemoterapi mielotoksik..

3. Pasien mendapatkan Filgrastim merk A atau Filgrastim merk B dengan dosis setiap kali suntik yaitu $300 \mu \mathrm{g}$ sebagai terapi neutropenia.

4. Data laboratorium angka leukosit dan neutrofil lengkap setiap siklusnya dalam 24 jam setelah post suntik terakhir.

\section{Kriteria eksklusi}

1. Pasien yang tidak ada evaluasi data absolute neutrophil count setelah injeksi filgrastim terakhir.

2. Pasien yang didiagnosis HIV.

3. Pasien yang sedang radioterapi.

\section{Analisis Data}

\section{Karakteristik subjek penelitian}

Karakteristik subjek penelitian disajikan menggunakan tabel kontingensi untuk melihat frekuensi kemudian dilakukan analisis terhadap perbedaan proporsi masing-masing variabel untuk melihat homogenitas subjek penelitian. Tampilan data frekuensi meliputi jenis kelamin, umur, jenis kanker, jenis 
regimen, siklus, grade neutropenia, jenis filgrastim, Body Mass Index, nilai ANC, dan waktu ANC recovery. Uji untuk data kategori (skala nominal atau ordinal) menggunakan uji Chi Square Goodness of fit. Sedangkan data numerik menggunakan uji-t independent berupa baseline ANC dan waktu NC recovery.

\section{Penentuan faktor-faktor yang berpengaruh pada waktu ANC recovery dan perbandingan efektivitas Filgrastim}

Penentuan faktor-faktor yang berpengaruh pada waktu ANC recovery dan perbandingan efektivitas filgrastim menggunakan analisis untuk mengetahui hubungan variabel dengan parameter waktu ANC recovery. Analisis survival yang digunakan dengan langkah-langkah sebagai berikut :

a. Analisis Bivariat

Analisis bivariat digunakan untuk melihat hubungan antara satu variabel dependen dan variabel independen dengan menggunakan metode Kaplan Meier. Tampilan data yang digunakan adalah kurva Kaplan Meier untuk melihat waktu tercapainya ANC recovery.

\section{b. Analisis Multivariat}

Tujuan analisis multivariat adalah melihat hubungan variabel independen dengan variabel dependen secara bersama-sama dengan melibatkan variabel perancu (counfounder). Uji statistik yang digunakan yaitu Regresi Cox dengan mengontrol pengaruh variabel yang diduga sebagai counfounder. Pemilihan kandidat menggunakan Regresi Cox dengan backward selection yaitu memilih variabel yang memiliki nilai $\mathrm{p}<$ 0,25 untuk dimasukkan dalam tahapan selanjutnya yaitu memeriksa apakah antar variabel terjadi interaksi. Setelah memeriksaan interaksi, kemudian diperiksa apakah diantara variabel independen terjadi interaksi dengan waktu. Jika asumsi proporsional terpenuhi $(p>0,05)$, pengujian dengan menggunakan Regresi Cox dengan time independent covariat, digunakan pemodelan dengan cox proportional hazard. Kemudian ditentukan variabel independen yang berpengaruh dengan survival time $(\mathrm{p}<$ $0,05)$ dan menentukan variabel counfounder kemudian dihitung nilai hazard ratio.

\section{Hasil dan Pembahasan}

\section{Karakteristik Subjek Penelitian}

Diperoleh sebanyak 80 subjek pasien keganasan limfoma dengan 192 kejadian neutropenia yang mendapatkan terapi filgrastim. Dari 80 subjek, hanya 43 subjek $(53,5 \%)$ yang memiliki kelengkapan data pada pengamatan 24 jam setelah suntik terakhir yang terdiri dari 72 kejadian neutropenia.

\section{Karakteristik pemakaian filgrastim pada masing-masing variabel confounder (perancu)}

Dari variabel confounder yang ada yaitu umur, jenis kelamin jenis kanker limfoma, jenis regimen kemoterapi, siklus, episode, dan grade neutropenia, absolut neutrophil count, body mass index menunjukkan data penyebaran frekuensi proporsi masing-masing variabel tersebut homogen $(p>0,05)$. Data tersebut menunjukan penggunaan filgrastim pada masing-masing variabel diberikan pada komposisi yang sama dan hasil frekuensi yang berimbang antara Filgrastim merk A dan Filgrastim merk B sehingga ketika membandingkan efektivitas filgrastim diharapkan menghasilkan data objektif dan tidak ada data yang tidak homogen. 
Tabel I. Karakteristik Pasien Keganasan Limfoma yang Menerima Kemoterapi Di RSUP Dr. Sardjito Yogyakarta Berdasarkan Berbagai Faktor Confounder

\begin{tabular}{|c|c|c|c|c|c|c|}
\hline \multirow{2}{*}{ No } & \multirow{2}{*}{ Variabel } & \multicolumn{2}{|c|}{ Filgrastim merk A } & \multicolumn{2}{|c|}{ Filgrastim merk $\mathbf{B}$} & \multirow[t]{2}{*}{$P$ value } \\
\hline & & $\mathbf{N}$ & $\%$ & $\mathbf{N}$ & $\%$ & \\
\hline \multirow[t]{3}{*}{1} & Jenis Kelamin & & & & & \\
\hline & Laki-laki & 15 & 40,5 & 22 & 59,5 & 0,250 \\
\hline & Perempuan & 18 & 51,4 & 17 & 48,6 & 0,866 \\
\hline \multirow[t]{10}{*}{2} & Umur & & & & & \\
\hline & $<30$ th & 1 & 33,3 & 2 & 66,7 & 0,56 \\
\hline & $30-34$ th & 2 & 66,7 & 1 & 33,3 & 0,56 \\
\hline & $35-39$ th & 2 & 40,0 & 3 & 60,0 & 0,65 \\
\hline & $40-44$ th & 2 & 100 & 0 & 0,0 & \\
\hline & $45-49$ th & 8 & 88,9 & 1 & 11,1 & 0,02 \\
\hline & $50-54$ th & 4 & 28,6 & 10 & 71,4 & 0,10 \\
\hline & $55-59$ th & 4 & 25,0 & 12 & 75,0 & 0,04 \\
\hline & $60-64$ th & 6 & 60,0 & 4 & 40,0 & 0,527 \\
\hline & $\geq 65$ th & 4 & 40,0 & 6 & 60,0 & 0,527 \\
\hline \multirow[t]{13}{*}{3} & BMI & & & & & \\
\hline & $<16 \mathrm{~kg} / \mathrm{m} 2$ & 0 & 0,0 & 0 & 0,0 & \\
\hline & $\begin{array}{l}\text { (kekurangan berat badan } \\
\text { parah) }\end{array}$ & & & & & \\
\hline & $16,0-16,9 \mathrm{~kg} / \mathrm{m} 2$ & 1 & 100,0 & 0 & 0,0 & \\
\hline & $\begin{array}{l}\text { (kekurangan berat badan } \\
\text { sedang) }\end{array}$ & & & & & \\
\hline & $\begin{array}{l}17,0-18,49 \mathrm{~kg} / \mathrm{m} 2 \\
\text { (kekurangan berat badan } \\
\text { ringan) }\end{array}$ & 4 & 44,4 & 5 & 55,6 & 0,739 \\
\hline & $18,5-24,9 \mathrm{~kg} / \mathrm{m} 2$ & 23 & 46,0 & 27 & 54,0 & 0,572 \\
\hline & (normal) & & & & & \\
\hline & $25-29,9 \mathrm{~kg} / \mathrm{m} 2$ & 5 & 50,0 & 5 & 50,0 & 1,000 \\
\hline & (preobesitas) & & & & & \\
\hline & $30-34,9 \mathrm{~kg} / \mathrm{m} 2$ & 0 & 0,0 & 1 & 100,0 & 0,564 \\
\hline & (obesitas kelas I) & & & & & \\
\hline & $\begin{array}{l}\geq 40 \mathrm{~kg} / \mathrm{m} 2 \text { (obesitas kelas } \\
\text { III) }\end{array}$ & 0 & 0,0 & 1 & 100,0 & \\
\hline \multirow[t]{3}{*}{4} & Jenis Kanker & & & & & \\
\hline & NHL & 29 & 45,3 & 35 & 54,7 & 0,453 \\
\hline & HL & 4 & 50,0 & 4 & 50,0 & 1,000 \\
\hline \multirow[t]{7}{*}{5} & Jenis Regimen & & & & & \\
\hline & CHOP & 4 & 50,0 & 4 & 50,0 & 1,000 \\
\hline & RCHOP & 18 & 41,9 & 25 & 58,1 & 0,286 \\
\hline & ICE & 0 & 0,0 & 3 & 100,0 & \\
\hline & RICE & 1 & 50,0 & 1 & 50,0 & 1,000 \\
\hline & RCEOP & 3 & 75,0 & 1 & 25,0 & 0,317 \\
\hline & RCOP & 0 & 0,0 & 1 & 100,0 & \\
\hline
\end{tabular}


Tabel I. Karakteristik Pasien Keganasan Limfoma yang Menerima Kemoterapi Di RSUP Dr. Sardjito Yogyakarta Berdasarkan Berbagai Faktor Confounder

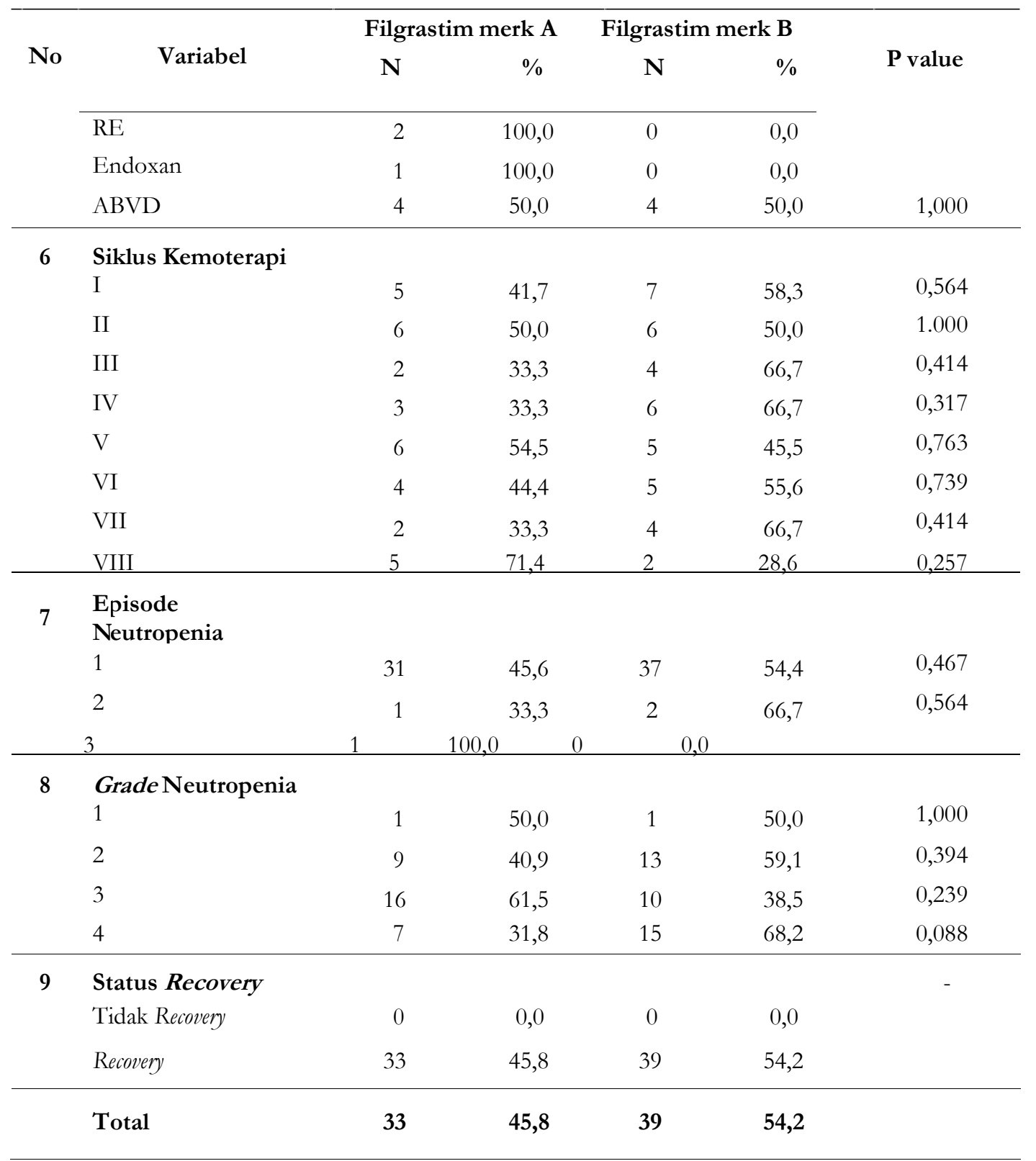

Keterangan : Karakteristik subjek penelitian variabel jenis kelamin, umur, BMI, jenis kanker, jenis regimen, siklus kemoterapi, episode neutropenia, grade neutropenia menggunakan Chisquare Goodness Of Fit.

\section{Baseline ANC masing-masing Filgrastim}

Berdasarkan data karakteristik baseline ANC Filgrastim merk A terdapat nilai rata-rata 809,58. Sedangkan Filgrastim merk B terdapat terdapat nilai rata-rata 698,41. Dari data tersebut menunjukkan nilai $\mathrm{p}>0,05$ menunjukkan karakteristik baseline ANC filgrastim merk A dan merk B mempunyai data yang homogen

\section{Data waktu ANC recovery}

Berdasarkan uji independent $t$ test setelah diuji ternyata memberikan nilai hasil $p$ value 0,001 yang berarti ada perbedaan waktu ANC recovery antara Filgrastim merk A dan Filgrastim merk B. Berdasarkan rata-rata waktu ANC Recovery Filgrastim merk A lebih 
pendek dibandingkan Filgrastim merk B.

Filgrastim merk A mempunyai rata-rata waktu 1,24 hari sedangkan filgrastim merk B yaitu 2,018 hari $(\mathrm{p}<0,05)$.

Tabel II. Data Waktu ANC Recovery Masing-masing Filgrastim

\begin{tabular}{ccccc}
\hline Jenis Filgrastim & Mean & SD & SE & P value \\
\hline Filgrastim merk A & 1,24 & 0,561 & 0,279 & 0,001 \\
Filgrastim merk B & 2,18 & 1,467 & 0,858 & \\
\hline
\end{tabular}

Keterangan : Karakteristik waktu ANC recovery masing-masing filgrastim menggunakan uji $\mathrm{t}$ independent.

Penentuan Faktor-Faktor yang Berpengaruh terhadap Waktu ANC Recovery

Berdasarkan analisis Kaplan Meier faktor yang signifikan mempengaruhi waktu ANC recovery yaitu jenis filgrastim, umur, dan grade neutropenia $(p<0,05)$.

\section{Jenis Filgrastim dengan waktu ANC recovery}

Perbandingan efektivitas jenis Filgrastim merk A dan B dengan parameter kecepatan waktu ANC recovery dilakukan analisis survival menggunakan grafik Kaplan Meier dan uji beda Log-rank yang menunjukkan bahwa pada waktu paruh pengamatan selama satu tahun, median time ANC recovery Filgrastim merk A adalah satu hari, sedangkan Filgrastim merk B adalah dua hari. Bila dilihat dari keseluruhan pengamatan selama dua tahun, mean time ANC recovery Filgrastim merk A sebesar 1,242 hari dan Filgrastim merk B 2,179 hari. Filgrastim merk A membutuhkan waktu recovery lebih cepat dibandingkan Filgrastim merk $\mathrm{B}(\mathrm{p}<0,05)$ berarti ada perbedaan yang bermakna antara recovery time Filgrastim merk A dan Filgrastim merk B.

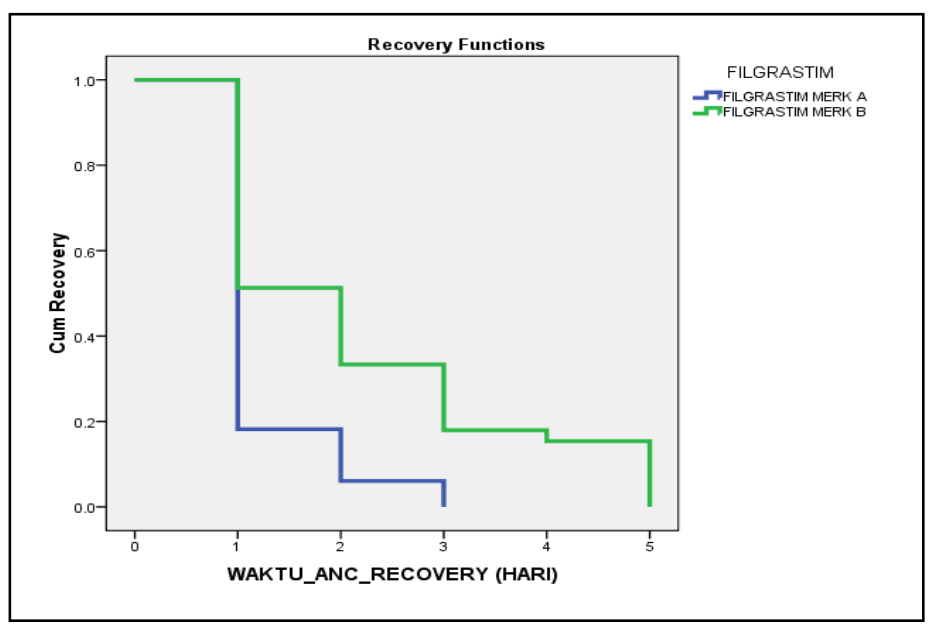

Gambar 1. Grafik Fungsi Recovery Filgrastim 
Umur dengan waktu ANC recovery

Hasil penelitian ini jika dilihat dari keseluruhan pengamatan selama dua tahun (mean time ANC recovery) menunjukkan umur $<30$ tahun dan umur 30-34 tahun waktu recovery-nyalebih cepat dibandingkan umur $\geq 65$ tahun $(p<0,05)$. Hal ini sesuai dengan teori umur $\geq 65$ tahun membutuhkan waktu recovery yang lebih lama (Pettengell et al.,2008).



Gambar 2. Grafik Fungsi Recovery Umur

Grade dengan waktu ANC recovery

Hasil waktu recovery tercepat adalah pada pasien Grade 2 dengan median recovery time sebesar satu hari dan mean recovery time sebesar 1,273 hari. Sedangkan grade yang paling lambat mencapai waktu recovery adalah grade 4 dengan median recovery time sebesar dua hari dan mean recovery time sebesar 2,545 hari $(\mathrm{p}<0,05)$. Semakin besar grade neutropenia (grade 4) akan mempengaruhi lamanya survival atau lamanya waktu pemakaian filgrastim (Lalami et al., 2006).

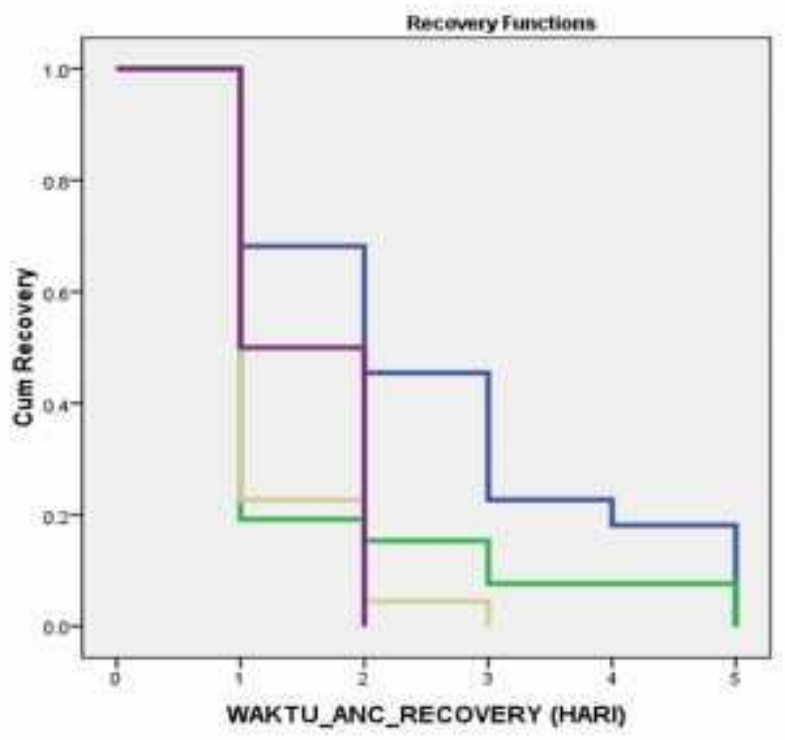

Gambar 3. Grafik Fungsi Recovery Grade 
Berdasarkan data tersebut, tahapan analisis survival selanjutnya yaitu dilakukan uji multivariat yang bertujuan untuk melihat hubungan variabel independen dengan variabel dependen secara bersama-sama dengan melibatkan variabel confounder, sehingga perbandingan efektivitas filgrastim dilihat dengan mempertimbangkan seluruh faktor yang dapat mempengaruhi waktu ANC recovery seperti jenis kelamin, umur, BMI, kanker, jenis regimen, filgrastim, siklus, episode, dan grade. Sebelum diperoleh model terakhir maka perlu dilakukan seleksi kandidat variabel yang akan diikutkan dalam analisis multivariat.

Hasil penelitian ini pada kelompok 24 jam post suntik terakhir didapatkan hasil uji Cox Regression (pada tabel 25) didapatkan hasil variabelvariabel tersebut memiliki nilai $\mathrm{p}>0,25$ maka tidak ada yang dapat dimasukkan ke dalam model multivariat.

\section{Perbandingan Efektivitas Filgrastim} Perbandingan efektivitas filgrastim pada penelitian ini menggunakan analisis survival dengan melalui tahapan uji bivariat Kaplan Meier dan multivariat regresi Cox yang telah dilakukan analisis statistik di pembahasan sebelumnya.

Pada analisis bivariat Kaplan Meier data 24 jam post suntik terakhir, Filgrastim merk A mempunyai waktu recovery yang lebih cepat dibandingkan Filgrastim merk B. Median time ANC recovery pada kejadian yang menggunakan Filgrastim merk A adalah satu hari, sedangkan Filgrastim merk B adalah dua hari. Mean time ANC recovery Filgrastim merk A sebesar 1,242 hari dan Filgrastim merk B 2,179 hari. Grafik Kaplan Meier pada data 24 jam post suntik terakhir (pada gambar 4) menunjukkan adanya perbedaan bermakna $(\mathrm{p}<0,05)$ pada recovery time (waktu ANC recovery) filgrastim yang dapat dilihat dari kurva yang tidak saling berpotongan.

$\begin{array}{lcr}\text { Pada } & \text { penelitian ini } & \text { setelah } \\ \text { dilakukan uji seleksi } & \text { kandidat } \\ \text { multivariat, } & \text { semua } & \text { variabel } \\ \text { menunjukkan nilai p }>0,25 & \text { sehingga } \\ \text { tidak dapat dilakukan tahap uji }\end{array}$

multivariat selanjutnya. Oleh karena itu, tidak ada variabel confounder yang secara signifikan mempengaruhi efektivitas filgrastim dalam mempengaruhi waktu ANC recovery. Perbandingan efektivitas filgrastim merujuk pada analisis Kaplan Meier yaitu Filgrastim merk A lebih cepat recovery dibandingkan Filgrastim merk B.

\section{Simpulan}

Filgrastim merk A lebih cepat mencapai waktu ANC recovery dibandingkan Filgrastim merk B dengan perbedaan signifikan $(\mathrm{p}<0,05)$.

\section{Ucapan Terimakasih}

Peneliti mengucapkan terima kasih kepada RS. Sardjito Yogyakarta sebagai tempat pelaksanaan yang digunakan dalam penelitian ini.

\section{Daftar Pustaka}

Bolis, S., Cocoroccio, E., Corti, C., Ferreri, M.J., Grillo, G., Omodeo, E.S., Tedeschi, L., Zillioli, V.R., 2013. Clinical implications, Safety, Efficacy of Recombinant Granulocyte -Colony Stimulating Factors and Pegylated Equivalen. Epidemiol. Biostatic Public Health 10, 4.

Crawford, J., Caserta, C., Roila, F., 2010. Hematopoietic growth factors: ESMO Clinical Practice Guidelines for the applications. Ann. Oncol. 21, v248- v251. doi:10.1093/annonc/mdq195

Lyman, G.H., Abella, E., Pettengell, R., 2014. Risk factors for febrile neutropenia among patients with cancer receiving chemotherapy: A systematic review. Crit. Rev. Oncol. Hematol. 90, 190-199. doi:10.1016/j.critrevonc.2013.12.0 06

Lalami, Y., Paesmans, M., Muanza, F., Barette, M., Plehiers, B., Dubreucq, L., Georgala, A., Klastersky, J., 2006. Can we predict the duration of chemotherapy-induced neutropenia in febrile neutropenic 
patients, focusing on regimenspecific risk factors? A retrospective analysis. Ann. Oncol. Off. J. Eur. Soc. Med. Oncol. ESMO 17,507-514. doi:10.1093/annonc/mdj092

Pettengell, R., Bosly, A., Szucs, T.D., Jackisch, C., Leonard, R., Paridaens, R., Constenla, M., Schwenkglenks, M., 2008. Multivariate analysis of febrile neutropenia occurrence in patients with non-Hodgkin lymphoma: data from the INC-EU Prospective Observational European Neutropenia Study. Br. J. Haematol. 144, 677-685. doi:10.1111/j.1365-

2141.2008.07514.x

Sevinc, A., Ozkan, M., Ozet, A., Dane, F., Oksuzoglu, B., Isikdogan, A., Ozdemir, F., Uncu, D., Gumus, M., Evrensel, T., Yaren, A., Kara, O., TekIn, S.B., 2014. 1501pcomparison of the Efficacy of Filgrastim (neupogen $($ ) and Biosimilar


Patients with ChemotherapyInduced Neutropenia: A Nationwide Observational Study. Ann. Oncol. 25, iv525-iv525. doi:10.1093/annonc/mdu356.22 